\title{
ESTIMATION OF CAUSAL RELATIONSHIP BETWEEN WORLD GOLD PRICES AND KSE 100 INDEX: EVIDENCE FROM JOHANSEN COINTEGRATION TECHNIQUE
}

\author{
Rizwan Raheem AHMED - Jolita VVEINHARDT \\ (Received: 11 August 2016; revision received: 10 November 2016; \\ accepted: 21 December 2016)
}

\begin{abstract}
The aspiration of this research paper is to investigate the impact of international gold prices on the equity returns of Karachi Stock Index (KSE100 index) of Pakistan Stock Exchange. The daily observations from January 1, 2000 - June 30, 2016 have been divided into three sub-periods along with the full sample period on the basis of structural breaks. Descriptive analysis used to calculate the average returns, which showed significant returns of KSE100 for the full sample, the first and the third sample periods as compared to gold returns. Standard deviation depicted the higher volatility in all the sample periods. Correlation analysis has shown an inverse relationship amid equity returns and gold returns, whereas, Philips-Perron and Augmented Dickey-Fuller tests have been employed, and time series data became stationary after taking the first difference. Johansen cointegration results have shown that the series are cointegrated in the full-sample and the first sample periods. Thus, this has demonstrated the long run association amid equity returns and gold returns in the first sub-sample and the full-sample periods. However, the second and the third sub-sample periods do not exhibit long-term association amid equity returns of KSE100 and gold returns. The outcomes of Granger causality approach identified bidirectional causation amid equity returns and gold returns in the full sample period in lag 2, and unidirectional causality has been observed from gold prices to stock prices in the full sample and the first sub-sample periods in lag 1 and lag 2 respectively.
\end{abstract}

Keywords: Gold price, KSE 100 index, Johansen cointegration, Philips-Perron test, ADF test, Granger casualty

JEL classification indices: C1, C32, E44, G14

Jolita Vveinhardt, corresponding author. Professor and Chief Researcher at the Faculty of Economics and Management, Vytautas Magnus University, Lithuania.

E-mail: Jolita.Vveinhardt@vdu.lt

Rizwan Raheem Ahmed, Professor at the Faculty of Management Sciences, Indus University, Karachi, Pakistan. E-mail: rizwanraheemahmed@gmail.com 


\section{INTRODUCTION}

International crises, such as the oil crisis of 1973, the energy crisis in the 2000s, the global financial crises in 2008 and the Japanese asset price crises (1986-2003) had a catastrophic impact on stock markets' investments. It brought gold in limelight as a substitution for equity investment. It is a popular belief that investment in gold is safe in times when investment in the financial market is risky. Gold is a different kind of asset because of the inverse relation with antagonistic market shocks (Baur - McDermott 2010; Filiz et al. 2013).

Owing to numerous factors in Pakistan, gold is considered as a lucrative investment. Its recent outstanding outcome has confirmed the wit behind this conventional investment. Under the fluctuating market scenarios, the investors used to shift their investment from risk bearing stock investment to more secure investment in gold. Gold is often traded in dollar terms. Under uncertain conditions, investment usually flows out of budding forex markets. In Pakistan, the market volatility makes the gold investment more lucrative. The increase in gold demand has been fuelled by both depreciation in Pak Rupee (PKR) and increase in gold prices. Thus, gold is an instrumental variable and can affect the Karachi Stock Exchange 100 index (KSE100) returns in Pakistan Stock Exchange (PSX).

The excessive demand for gold in Pakistan has caused a rise in gold prices. Apart from that, numerous other reasons are responsible for the rise in gold prices in Pakistan. Gold is considered as a secure investment. The absence of credit risk is attached to the gold investment. Even in the worst economic conditions, the liquidity of gold is established. Gold is also considered as the last resort of asset. The financial and economic systems of ancient ages and civilisations of the world demonstrates that nations have uninterruptedly expended gold as collateral versus borrowings under the struggling balance of payment stances (Shahzadi Chohan 2010).

For centuries, the majority of the population of Pakistan and India has been using gold as an alternative source of investment. Specifically, in the South Asian region gold has been used for jewelry, helping tool in hard times, and a symbol of status.

Figure 1 depicts the trends of international gold prices and KSE100 index during the considered time period, and shows an upward trend in the international gold prices as an alternative source of investment because of the risk-free investment opportunity. Similarly, the stock prices of KSE100 index are also exceptionally well during this time period. Figure 1 also compares the trends of KSE100 index and the international gold prices during January 1, 2000 - June 30, 2016.

This research paper establishes the causal and long-term relationship between KSE100 stocks and returns to gold in the international market. It is important to 


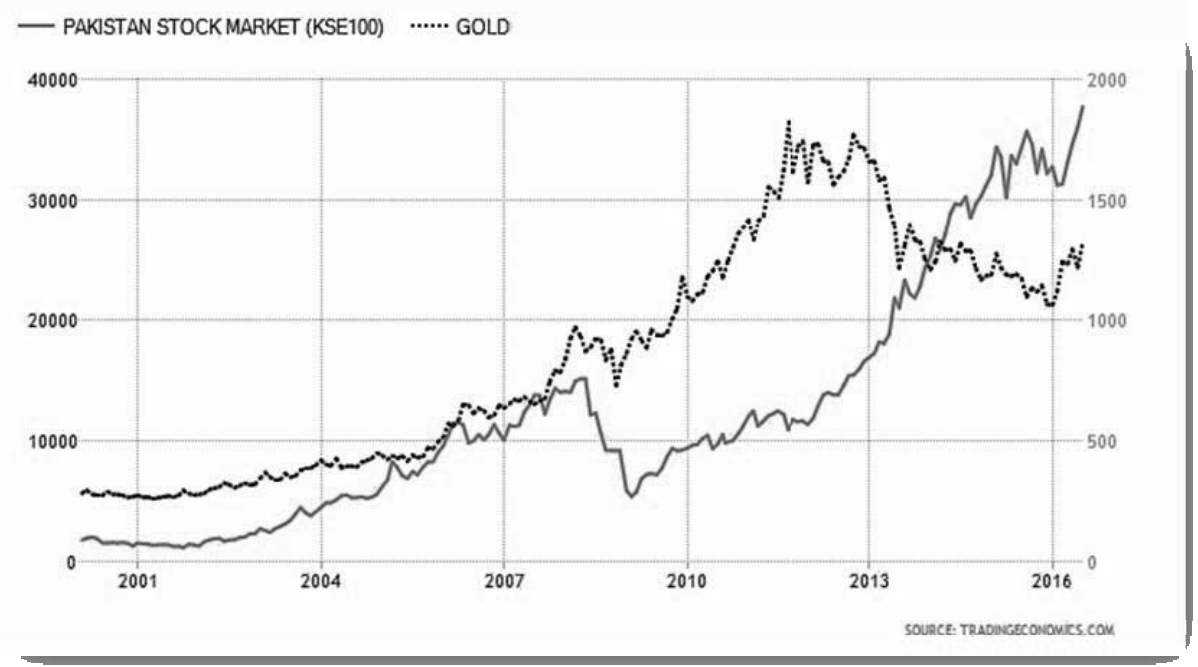

Figure 1. Movement of gold prices (USD/Ounce) and stock price 100 index

Source: Trading Economics (2016).

know that there is more than one element which influences the equity and gold returns. According to the investors' point of view, these factors are alternatives to one another, responsible for price movement that are articulated as contraries in the previous literature. Specifically, gold is not considered as a local instrument of investment, but it is regarded as an international de facto commodity. Therefore, the gold prices do not only depend on local dynamics but also on the macroeconomic considerations. We have mentioned, gold prices are set in terms of the US dollar, thus, these prices are also dependent on the political and economic conditions of the World. Moreover, the crude oil prices also influence the international gold prices (Koutsoyiannis 1983; Ghosh et al. 2002; Vural 2003; Tully - Lucey 2005; Topcu 2010; Toraman et al. 2011). Similarly, the equity prices depend on numerous macroeconomic indicators, for instance, rate of inflation, exchange and interest rates, imports and exports, government debts, gold and crude oil prices, and economic growth (Fama 1981; Gong - Mariano 1997; Cheung - Lilian 1998; Bali - Cinel 2011).

The Karachi Stock Exchange (KSE) was the oldest equity market in South Asia, and the largest one in Pakistan before the merger of the three stock markets such as KSE, Lahore stock exchange and Islamabad stock exchange. On January 11, 2016, these three markets were merged and renamed as the Pakistan Stock Exchange (PSX). As on November 17, 2017, 581 companies in 35 sectors are listed at PSX with total market capitalization of PKR8506.433 billions 
(USD80.249 billions). Pakistan Stock Exchange gained the status of emerging market in May 2017.

Pakistan Mercantile Exchange (PMEX) is a commodity market where gold and other commodities are being traded. PMEX is the platform for individual and institutional investors, where they trade all these commodities including gold. The online trading services are being provided for 21 hours to the customers, PMEX is facilitating trading of gold, silver, and crude oil. There are several deals for each commodity; however, gold is traded in eight different contracts, for instance, gold $1 \& 100$ ounces, gold $1,50 \& 100$ tola $^{1}$, gold $100 \mathrm{~g} \mathrm{\&} 1 \mathrm{~kg}$, and mini-gold contracts.

The prime objective of this research is to investigate the association amid equity returns of KSE100, and changes in international gold prices. Another aim is to explore the short and/or the long run causal relations, and also the direction of causation between these variables. The daily time series data of international gold prices were taken from the official website of Trading Eonomics (2016), however, the daily data for KSE100 index were obtained from the official website of PSX. The time horizon for the undertaken study was selected from January 1, 2000 to June 30, 2016 (PSX 2016). As shown in Figure 1, there are several structural breaks during the stated time period; therefore, we have divided the data period into three sub-periods along with the full sample period as follows:

Full sample period: Janurary 1, 2000, through June 30, 2016.

First sub-sample period: January 1, 2000, through June 30, 2008.

Second sub-sample period: July 1, 2008, through June 30, 2012.

Third sub-sample period: July 1, 2012, through June 30, 2016.

The significance of this research is manyfold because very few researches have been carried out on the specific relationship between world gold prices and KSE100 returns. Most of the researches have been conducted on domestic gold price plus other macroeconomic variables in order to check the relationship with KSE100. Another distinguished aspect of our research is the data, which has been taken on a daily basis, and total 4060 observations (after adjustments) were recorded and used for analysing the relationships of variables for all three subperiods along with the full sample period. Secondly, the performance and growth of KSE100 index have been exceptionally well during the last few years, and it touches the 55,000 index. Hence, this exceptional growth of KSE100 index has captured the attention of foreign investors, for example, China has purchased the $40 \%$ shares of KSE100. Thus, this makes a clear differentiation for KSE100 from other regional and emerging markets and provides a substance of great relevance

1 Tola is a Hindi term which is used in India and some other Asian countries to measure gold. At present, one tola gold is equivalent to 10 grams of gold. 
and curiosity for researchers to re-investigate the characteristics of KSE100 index. This foundation has multiplied the significance of this study. Hefty developments are also observed in gold prices worldwide in general and in Pakistan in particular in recent times. This has necessitated re-examining the association amid the equity returns of KSE100 index and the international gold returns. The outcomes of the undertaken research will offer valuable investment decision inputs to the investors of the stock and gold market. Numerous research constructs are influencing the equity returns, and international gold prices happen to be an important variable. Hence the results of undertaken research are anticipated to serve an eye and ear to the stock and the gold investors.

The rest of the study is structured as follows: Section 2 overviews the relevant studies on the link among gold prices and important economic and capital markets' variables, Section 3 comprises of the empirical framework and estimation techniques, Section 4 deals with estimations and results, whereas Section 5 contains the discussion and Section 6 the conclusion.

\section{LITERATURE REVIEW}

The findings of previous researches are hybrid; several studies are in favour of long-term relationships between changes in gold rate and equity returns. However, numerous researches also concluded that gold prices and stock returns do not have any relationship in the long run.

Developed and European stock markets. According to Pritchard (2010), the global financial crises of 2008 and its transacted effects emerged as economic recession worldwide from 2008 to 2012. This economic crunch had crashed all the financial markets of the world, therefore, this catastrophe has increased the importance of gold, and investors have again diverted towards the investment opportunities in the gold market. The money and stock markets of the world have abruptly deteriorated, and consequently, money and equity markets of the world have collapsed. Hence, besides this factor, there are several other reasons, which have appreciated the demand for gold, and prices of gold have increased sharply.

Baur - Lucey (2010) explained that in some European countries like the UK, Germany, and in the USA, gold is considered as a safe mode of investment as compared to stocks. Baur - McDermott (2010) have studied both the emerging countries and the developed ones in this regard and concluded that gold is a safe heaven and hedging for US stock markets, but has not shown the same characteristic in case of Japan, Australia, Canada and BRIC countries. Bali - Cinel (2011) have studied the relationship between gold prices and equity returns of ISE in the 
Turkish economy. They have used the panel analysis to examine the influence of gold prices on the equity market and also investigated the quantum and directionality of this effect. The results of their study demonstrated that there is no direct impact on the equity market, but the gold prices are one of the other factors which have a definite influence on the equity returns of the ISE in case of Turkey.

Sumner et al. (2010) tried to discover the mutual dependence of equity returns, bonds, and gold returns by observing the returns of gold and instabilities. As per this research, gold is just supportive in predicting stock behavioural movements. Büyüksalvarc1 (2010) studied the relationship between the equity returns, and interest rate, exchange rate, CPI, money market, oil prices, and gold prices. The results of the study have shown that the gold returns have an inverse relation to the equity returns. Omağ (2012) has investigated the association between gold prices and other macroeconomic indicators including stock prices of ISE in the Turkish economy. He found that the gold prices significantly influence the exchange rate and the equity returns of the ISE index. Yahyazadehfar - Babaie (2012) have shown an inverse relationship between equity returns and various economic indicators, for instance, changes in gold prices and interest rate.

Moore (1990) has demonstrated an inverse association between gold prices and stock returns. It means when stock markets deteriorate the gold prices increase or the other way round. Wang et al. (2010) have investigated the causal association between different macroeconomic indicators including gold prices, and equity returns of differnt stock markets such as Japan, Germany, Taiwan, China, and the United States, and found the long-run relationship of gold prices with equity returns except in the United States. They have used Johansen cointegration to derive the long-term causal relationship. Another study conducted by Aksoy - Topcu (2013) analysed the relationship in short and long-run changes in gold prices, equity returns, government debt securities, PPI, and CPI in Turkey. They found an inverse relationship between equity returns and gold returns, and affirmative association amid gold price changes and PPI centered inflation rate.

Smith (2002) has investigated an association between equity returns and the changes in gold prices in both long and short run. The researcher used three different prices of gold; from the London exchange varying from 10:30 am, 15:00 pm and closing time, and for the equity returns he has considered 18 countries' stock market indices. The results have demonstrated an inverse association between the equity returns of different markets and the gold returns in the short run, moreover, this research concluded that there is no evidence of a long-run association between the equity returns and gold returns. The findings revealed by previous research studies including Blose - Shiech (1995), Mahdavi - Zhou (1997), and Chan - Faff (1998) have demonstrated that the gold price changes are based on the inflation pressure. 
South Asian stock markets. Since gold has unique values and characteristics in the South Asian countries, and it is thought that savings are risk-free in gold investment, which can be liquidated at any hard time, therefore, people prefer to save money in the shape of gold. Secondly, gold jewelry and ornaments have been considered to be the pride in these societies for centuries. Thus, the gold price has a distinguished relationship with stock returns in India, Pakistan, Bangladesh, Iran, etc.

Bhunia - Mukhuti (2013) have studied the influence of gold returns on equity returns of Indian stock markets (Bombay Stock Exchange \& National Stock Exchange of India) and concluded that there was no causal association between changes in local gold rates and stock returns of BSE and NSE. Moreover, they have evidenced that there was no bidirectional causality between the analysed variables. Baig et al. (2013) concluded that the gold rates and prices of oil do not have any effect on the equity returns of KSE100 or the other way round. Sharma - Mahendru (2010) have examined the association amid forex rates, prices of gold, and equity returns in the Indian context and found a significant association between the variables of interest. Shahzadi - Chohan (2010) have found a negative causal association between change in gold rates and equity returns of KSE100 index. Kaliyamoorthy - Parithi (2012) researched on the link between the NSE index and the gold prices and found that no association existed between the change in gold rates and the stock index in India. However, another research has been carried out in India by Bhunia - Das (2012) which has shown a relationship between the gold rates and the returns of equities in India. They have demonstrated that the selected indicators influence each other, whereas gold prices change in cycle with equity returns during and after the global financial crunch. Moreover, the results of the study demonstrate that the Indians have started to recognise gold not only as jewelry but also as an instrument of investment.

Mishra - Mohan (2012) studied the association between Indian financial markets and price changes in gold, and demonstrated a strongly interlinked relationship between these variables. Mishra et al. (2010) have shown a positive relation between gold prices and equity markets in India, and also confirmed that both equity returns and gold prices are essential for predicting each other. Gwilym et al. (2011) have conducted an important research on the association of equity returns and changes in gold prices and explicated the illustrative influence of gold rates with respect to future return to gold investment. Samadi et al. (2012) studied the causal relationship between inflation, gold price, oil prices, exchange rate, and equity returns of the Tehran Stock Exchange. This research determined the influence of macroeconomic indicators on equity returns from 2001 to 2010 using the GARCH model. The result brings out that a causative association held 
among gold returns, interest rate, and exchange rate while no relationship lies with liquidity and price of oil.

Miscellaneous stock markets. Nguyen et al. (2012) have also tried to establish the association between gold markets and equity markets. For this purpose, the market data from eight countries comprising Singapore, Japan, UK, Malaysia, Indonesia, Philippines, Thailand and the United States were collected. This research reveals that most of the stock markets displayed unavailability of dependency with the gold price. While Kuala Lumpur equity market has right-end dependency on gold returns and Japan, Indonesia, and the Philippines markets have left-end dependency. Mulyadi - Anwar (2012) have studied the gold and stock investments, and have concluded that the gold investments are more profitable as compared to stocks in the equity markets of Singapore, Malaysia, and Indonesia.

Pilinkus (2009) conducted a very important study and checked the influence of 40 macroeconomic variables including gold prices on stock prices in Lithuanian market. He has demonstrated the interrelated affect and significant influence of all macroeconomic indicators on stock prices. Lawrence (2003) determined through his study that gold is one of the most efficient diversifiers of the portfolio. Thus, it has no interlinks with the dynamics of macroeconomics as compared to other financial assets and a weak correlation lies between the return on gold and stocks.

\section{EMPIRICAL FRAMEWORK}

Descriptive analysis is used to calculate the average returns and volatility; whereas correlations analysis is used to establish the relationship between stock returns and gold returns. We have employed two stationary techniques such as PhilipsPerron and Augmented Dickey-Fuller for the stationarity purposes, Johansen cointegration has been employed to examine the existence and number of cointegrating vectors, and lastly, for causality purposes, Granger test has been used.

Change in KSE100 index. KSE100 returns are computed by (1) as follows:

$$
S P_{(t)}=\left(C_{t} / C_{t-1}\right)-1
$$

where: $S P_{(t)}$ are the returns of KSE100 index in a daytime ' $t$ ' and $C_{t} \& C_{t-1}$ referred for closing and opening points of stock prices in daytimes ' $t$ ' \& ' $t-1$ ', respectively.

Change in gold prices. The gold prices (GP) are calculated by (2) as follows: 


$$
G P_{(t)}=\left(G P_{t} / G P_{t-1}\right)-1
$$

where: $G P_{(t)}$ are the gold returns in daytime ' $t$ ', and $G P_{t} \& G P_{t-1}$ are gold prices in the daytime, and ' $t$ ' $\&$ ' $t-1$ ' are closing and opening daytimes, respectively.

Correlation analysis. Karl Pearson Correlation analysis technique is applied to test the interconnection among the variable of interest for this study.

$$
r=\frac{n \sum_{i=j=1}^{n} x_{i} y_{j}-\sum_{i=1}^{n} x_{i} \sum_{j=1}^{n} y_{j}}{\sqrt{n \sum_{i=1}^{n} x_{i}^{2}-\left(\sum_{i=1}^{n} x_{i}\right)^{2}}} \times \frac{1}{\sqrt{n \sum_{j=1}^{n} y_{j}^{2}-\left(\sum_{j=1}^{n} y_{j}\right)^{2}}}
$$

where: $r=$ Correlation coefficient, $x, y=$ Two variables' returns and $n=$ No. of observations.

Unit Root Tests. The initial step is to confirm the stationarity of data series, therefore, first, we check the stationarity of the data and for this purpose numerous testing methods are available but the most efficient and commonly practiced methods are Philips and Perron (1988), and Augmented Dickey-Fuller (1979, 1981). The generalised equation for Philips-Perron (PP) can be expressed in (4) as follows:

$$
\Delta y_{t}=p y_{t-1}+e_{t} .
$$

The PP test could be elaborated as the null hypothesis if $p=0$, Philips-Perron (PP) has $Z t \& Z p$ statistics, which have similar asymptotic distributions as the normalized bias statistics and ADF t-statistic have possessed. The biggest advantage of the PP test as compared to the ADF test is that the results of PP test are more accurate and robust to overall procedures of heteroskedasticity in the white noise error ' $e_{t}$ ' term. Moreover, there is no need to stipulate a lag length in PP test for the regression test. However, ADF can be expressed in (5) as follows:

$$
\Delta y_{t}=\alpha_{0}+\alpha_{1} y_{t-1}+\sum_{i=1}^{n} \alpha \Delta y_{t}+e_{t}
$$

where: ' $t$ ' is a time period, ' $y$ ' is time series, ' $n$ ' is optimum number of lags, $\alpha_{0}$ is known as the constant value, and ' $e$ ' is referred to as white noise error term.

Johansen cointegration testing approach. This approach makes the usage of cointegration between the series of similar order by creating a cointegration equation. The trend is stationary due to the constant difference between the two series, and it is feasible to describe a long-term stable relationship between the 
series (Hall - Henry 1989). If cointegration is not deployed, it shows no long-run relationship between the two series (Dickey et al. 1991).

Precisely, if the time series ' $y_{t}$ ' is known as the vector for ' $n$ ' number of stochastic variables, subsequently there will be an existence of ' $p$-lag' vectors of auto regression besides the Gaussian errors, (6) is the mathematical form and could be written as:

$$
\Delta y_{t}=\mu+\Delta_{1} y_{t-1}+\ldots \ldots \ldots \ldots+\Delta_{p} y_{t-p}+\varepsilon_{t} .
$$

In equation (6), the time series ' $y_{t}$ ' is denoted for $(n x l)$ vectors of the considered variables, which are integrated of orders, whereas, the term ' $\varepsilon_{t}$ ' is known for $(n x l)$ number of vectors innovations. Thus, the above (6) could be written in the form of (7) as follows:

$$
\Delta y_{t}=\mu+\eta y_{t-1}+\sum_{i=1}^{n-1} \tau_{t} \Delta y_{t-1}+\varepsilon_{t}
$$

where: $\eta=\sum_{i=1}^{p} A_{i-1}$ and $\tau_{t}=\sum_{j=i+1}^{p} A_{j}$.

Johansen (1991, 1995), and Johansen - Juselius (1990) methods are used to classify the number of vectors for cointegration. They have devised two statistic tests in which first test is known as the Trace test or simply $\lambda$-trace in order to check the null hypothesis of a distinct number of vectors under the condition of less than or equal to the probability ' $p$ ' in comparison of unrestricted alternative $p=r$. Now, the (8) is the mathematical form of Trace test, and expressed as follows:

$$
\lambda_{\text {trace }}(r)=-T \sum_{i=r+1}^{n} \ln \left(1-\hat{\lambda}_{r+1}\right)
$$

where: ' $T$ ' is known as the number of utilizable observations, and the term ' $\lambda r+1$ ' is known as the estimated Eigenvalue from the matrix, thus, the second test statistic is called as the Maximum Eigenvalue test or simply $\lambda$-max, and it could be estimated from (9) as follows:

$$
\lambda_{\max }(r, r+1)=-T \ln \left(1-\hat{\lambda}_{r+1}\right) .
$$

The mathematical form (9) includes testing the null hypothesis of whether there is ' $r$ ' number of cointegrating vectors in contrast to the alternative hypothesis, which is $(r+1)$ cointegrating vector.

Granger Causality Technique. The Granger theorem states, if two factors are cointegrated then unidirectional Granger causality must exist, and this leads towards the position in order to ascertain the relationship by the error correction model (ECM) for the confirmation of causation. The pair-wise Granger causal- 
ity technique helps in highlighting the causal relationship of each factor. Since we have to select lag in order to get proper results that are user-quantified. It is also noted, if data series are not stationary at $\mathrm{I}(0)$, and no cointegration existed amongst the factors then it is necessary to transform the series by taking first difference at I(1) and (10) would be applied (Akash et al. 2011):

$$
Q_{\text {prob }}\left(W_{t+n} \mid \Phi_{t}\right)=Q_{\text {prob }}\left(W_{t+n} \mid \omega_{t}\right)
$$

where: $Q_{\text {prob }}$ is called as conditional probability, ' $\Phi_{t}$ ' are known as the information, which was fixed at ' $t$ ' time period, whereas, for the historical values ' $W t+n$ ' and ' $\omega_{t}$ ', are set of information, which is comprised of different values, and ' $t+n$ ' is known as the period of time. (10) is referred as an unlimited regression equation, which helps determine the unrestricted or unlimited residual sum of square (RSSR) and eliminate the lagged values for the selected macroeconomic indicator. In this method, the 1st differential is used to recognize the controlled regression in order to acquire the controlled residual sum of square (RSSR), finally integrated to order one ought to be retained the ' 0 ' for entire readings of the Fstatistic. The null hypothesis could be checked by using (11):

$$
F=\frac{\left(R S S R-R S S U R / k-k_{0}\right)}{(R S S / N-k)}
$$

From (11), we could draw the inference that if the value of $F$-statistic surpasses the critical value of the selected significance level, and $p$-value associated to F-Statistic is less than 0.05 then we reject the null hypothesis.

\section{ESTIMATION AND RESULTS}

Since there are three structural breaks in the complete sample period, i.e. from January 1, 2000 to June 30, 2016, we have estimated our results according to the following four estimation periods:

Full sample period: Jan 1, 2000 - June 30, 2016. First of all, we have estimated our results on the basis of overall data time period, however, three prominent structural breaks can be seen from Jan 1, 2000 to June 30, 2016, as depicted by Figure 1, therefore, results cannot be generalised for the whole data time period. But first we have checked the overall impact of the variables over the full sample period, and then divided the the full period into three sub-periods according to the 
structural breaks in order to compare the changes in sub-sample time periods with the full sample period. Thus, following are the results of the full sample period.

Descriptive analysis. Table 1 represents the descriptive analysis of equity returns of KSE100 and the daily returns of international gold prices. The descriptive statistics show that the average returns to stock for the full sample period was $0.08 \%$ per day or $24 \%$ annually, whereas, for gold prices, the average return was $0.04 \%$ per day or $12 \%$ annually. Standard deviation shows higher volatility in full sample period and almost every sub-sample period for both stock returns and gold returns. Moreover, Kurtosis values reject normality in both data series. Total observations of 4060 were considered after adjustments.

Correlation analysis. Table 2 exhibits the negative correlation between equity returns and gold returns in the full sample period thus demonstrate an inverse association between KSE100 returns and returns of gold. It is estimated from the full sample period that if stocks returns increase then gold returns decrease or the other way round. It can be concluded that the investors are very much rational about the downfall of any market, thus they switch their investments from the respective markets whenever they experience any downfall.

Augmented Dickey-Fuller and Philips-Perron Unit Root Tests. The outcomes of Table $3 A$, Table $3 B$, Table $3 C$ and Table $3 D$ indicate the findings of Philips-Perron, and Augmented Dickey-Fuller tests for the full sample period, first, second, and third sub-samples, respectively. The results of the tables show

Table 1. Descriptive analysis

\begin{tabular}{|c|c|c|c|c|c|c|c|c|}
\hline Sample period & $\begin{array}{c}\text { Macroeconomic } \\
\text { variables }\end{array}$ & $\mathrm{N}$ & $\begin{array}{l}\text { Mini- } \\
\text { mum }\end{array}$ & $\begin{array}{l}\text { Maxi- } \\
\text { mum }\end{array}$ & Mean & \begin{tabular}{|c|} 
Std. \\
Devia- \\
tion
\end{tabular} & $\begin{array}{l}\text { Skew- } \\
\text { ness }\end{array}$ & Kurtosis \\
\hline \multirow{3}{*}{$\begin{array}{l}\text { Full sample } \\
\text { period (Jan 1, } \\
\text { 2000-June 30, } \\
\text { 2016) }\end{array}$} & KSE100 index & 4061 & -0.08 & 0.09 & 0.0008 & 0.01372 & -0.22 & 3.764 \\
\hline & Gold Prices & 4061 & -0.1 & 0.09 & 0.0004 & 0.01163 & -0.284 & 5.21 \\
\hline & Valid N (listwise) & 4061 & & & & & & \\
\hline \multirow{3}{*}{$\begin{array}{l}\text { First sub-sam- } \\
\text { ple period (Jan } \\
1,2000-J u n e \\
30,2008)\end{array}$} & KSE100 index & 2078 & -0.08 & 0.09 & 0.0011 & 0.01568 & -0.154 & 3.127 \\
\hline & Gold Prices & 2078 & -0.08 & 0.09 & 0.0006 & 0.01115 & -0.14 & 5.012 \\
\hline & Valid N (listwise) & 2078 & & & & & & \\
\hline \multirow{3}{*}{$\begin{array}{l}\text { Second sub- } \\
\text { sample period } \\
\text { (Jul 1, 2008- } \\
\text { June 30, 2012) }\end{array}$} & KSE100 index & 993 & -0.05 & 0.05 & 0.0001 & 0.01346 & -0.316 & 2.191 \\
\hline & Gold Prices & 993 & -0.06 & 0.08 & 0.0008 & 0.0133 & -0.2 & 2.999 \\
\hline & Valid N (listwise) & 993 & & & & & & \\
\hline \multirow{3}{*}{$\begin{array}{l}\text { Third sub-sam- } \\
\text { ple period (Jul } \\
\text { 1, 2012-June } \\
30,2016)\end{array}$} & KSE100 index & 990 & -0.05 & 0.16 & 0.0012 & 0.00993 & 3.511 & 62.47 \\
\hline & Gold Prices & 990 & -0.1 & 0.06 & -0.0002 & 0.01089 & -0.576 & 9.482 \\
\hline & Valid N (listwise) & 990 & & & & & & \\
\hline
\end{tabular}

Source: Own research. 
Table 2. Correlation analysis

\begin{tabular}{|c|c|c|c|c|}
\hline Sample period & Correlations & Variables & KSE100 index & Gold prices \\
\hline \multirow{6}{*}{$\begin{array}{l}\text { Full sample period } \\
\text { (Jan 1, 2000-June } 30 \text {, } \\
2016 \text { ) }\end{array}$} & Pearson Correlation & \multirow{3}{*}{ KSE100 index } & 1 & -0.013 \\
\hline & Sig. (2-tailed) & & & \\
\hline & $\mathrm{N}$ & & 4061 & 4061 \\
\hline & Pearson Correlation & \multirow{3}{*}{ Gold prices } & -0.013 & 1 \\
\hline & Sig. (2-tailed) & & & \\
\hline & $\mathrm{N}$ & & 4061 & 4061 \\
\hline \multirow{6}{*}{$\begin{array}{l}\text { First sub-sample } \\
\text { period-1 (Jan 1, 2000- } \\
\text { June 30, 2008) }\end{array}$} & Pearson Correlation & \multirow{3}{*}{ KSE100 index } & 1 & -0.011 \\
\hline & Sig. (2-tailed) & & & \\
\hline & $\mathrm{N}$ & & 2078 & 2078 \\
\hline & Pearson Correlation & \multirow{3}{*}{ Gold prices } & -0.011 & 1 \\
\hline & Sig. (2-tailed) & & & \\
\hline & $\mathrm{N}$ & & 2078 & 2078 \\
\hline \multirow{6}{*}{$\begin{array}{l}\text { Second sub-sample } \\
\text { period-2 (Jul 1, 2008- } \\
\text { June } 30,2012)\end{array}$} & Pearson Correlation & \multirow{3}{*}{ KSE100 index } & 1 & -0.008 \\
\hline & Sig. (2-tailed) & & & \\
\hline & $\mathrm{N}$ & & 993 & 993 \\
\hline & Pearson Correlation & \multirow{3}{*}{ Gold prices } & -0.008 & 1 \\
\hline & Sig. (2-tailed) & & & \\
\hline & $\mathrm{N}$ & & 993 & 993 \\
\hline \multirow{6}{*}{$\begin{array}{l}\text { Third sub-sample } \\
\text { period-3 (Jul 1, 2012- } \\
\text { June 30, 2016) }\end{array}$} & Pearson Correlation & \multirow{3}{*}{ KSE100 index } & 1 & 0.057 \\
\hline & Sig. (2-tailed) & & & \\
\hline & $\mathrm{N}$ & & 990 & 990 \\
\hline & Pearson Correlation & \multirow{3}{*}{ Gold prices } & 0.057 & 1 \\
\hline & Sig. (2-tailed) & & & \\
\hline & $\mathrm{N}$ & & 990 & 990 \\
\hline
\end{tabular}

Source: Own research.

that the log series of KSE100 and gold rates are non-stationary at the level form as the absolute T-statistic values are less negative as compared to the absolute critical values at $1 \%$ level of significance. Moreover, $p$-values associated to their corresponding $T$-values are greater than 0.05 . Hence, it is concluded that the null hypothesis for the existence of unit root has not been rejected, thus, there is no evidence of stationarity at the level form. However, they became stationary series at the first difference because the values of absolute $T$-statistic are more negative as compared to the absolute critical values at $1 \%$ level of significance and corresponding $p$-values are less than 0.05 . Therefore, the null hypothesis of the unit root has been rejected, and thus the data series of the full sample, first, second and third sub-sample periods are integrated of order one or I(1) as discussed earlier in the methodology section. 
Table 3A. Unit Root Tests for Stationarity

Phillips-Perron \& Augmented Dickey-Fuller Tests statistic

Full sample period from Jan 1, 2000 to June 30, 2016

\begin{tabular}{|c|c|c|c|c|c|c|c|}
\hline \multicolumn{4}{|c|}{ Null Hypothesis: D(LKSE100) has a unit root } & \multicolumn{4}{|c|}{ Null Hypothesis: D(LGP) has a unit root } \\
\hline & & Adj. $\mathrm{t}-$ Stat & Prob.* & & & Adj. t-Stat & Prob.* \\
\hline \multicolumn{2}{|c|}{ Phillips-Perron test statistic } & -36.082 & 0.0000 & \multicolumn{2}{|c|}{ Phillips-Perron test statistic } & -41.330 & 0.0000 \\
\hline \multirow{3}{*}{$\begin{array}{l}\text { Test critical } \\
\text { values: }\end{array}$} & $1 \%$ level & -3.4342 & & \multirow{3}{*}{$\begin{array}{l}\text { Test critical } \\
\text { values: }\end{array}$} & $1 \%$ level & -3.4342 & \\
\hline & $5 \%$ level & -2.8631 & & & $5 \%$ level & -2.8631 & \\
\hline & $10 \%$ level & -2.5677 & & & $10 \%$ level & -2.5677 & \\
\hline
\end{tabular}

\begin{tabular}{|c|c|c|c|c|c|c|c|}
\hline \multicolumn{4}{|c|}{ Null Hypothesis: D(LKSE100) has a unit root } & \multicolumn{4}{|c|}{ Null Hypothesis: D(LGP) has a unit root } \\
\hline & & t-Stat. & Prob.* & & & t-Stat. & Prob.* \\
\hline \multicolumn{2}{|c|}{$\begin{array}{l}\text { Augmented Dickey-Fuller } \\
\text { test statistic }\end{array}$} & -36.052 & 0.0000 & \multicolumn{2}{|c|}{$\begin{array}{l}\text { Augmented Dickey-Fuller } \\
\text { test statistic }\end{array}$} & -41.285 & 0.0000 \\
\hline \multirow{3}{*}{$\begin{array}{l}\text { Test critical } \\
\text { values: }\end{array}$} & $1 \%$ level & -3.4342 & & \multirow{3}{*}{$\begin{array}{l}\text { Test critical } \\
\text { values: }\end{array}$} & $1 \%$ level & -3.4342 & \\
\hline & $5 \%$ level & -2.8631 & & & $5 \%$ level & -2.8631 & \\
\hline & $10 \%$ level & -2.5677 & & & $10 \%$ level & -2.5677 & \\
\hline
\end{tabular}

Note: *MacKinnon (1996) one-sided p-values.

Source: Own research.

Table 3B. Unit Root Tests for Stationarity

Phillips-Perron \& Augmented Dickey-Fuller Tests statistic

First sub-sample period from Jan 1, 2000 to June 30, 2008

\begin{tabular}{|c|c|c|c|c|c|c|c|}
\hline \multicolumn{4}{|c|}{ Null Hypothesis: D(LKSE100) has a unit root } & \multicolumn{4}{|c|}{ Null Hypothesis: D(LGP) has a unit root } \\
\hline & & Adj. t-Stat & Prob.* & & & Adj. t-Stat & Prob.* \\
\hline \multicolumn{2}{|c|}{ Phillips-Perron test statistic } & -26.7690 & 0.0000 & \multicolumn{2}{|c|}{$\begin{array}{l}\text { Phillips-Perron test } \\
\text { statistic }\end{array}$} & -28.3688 & 0.0000 \\
\hline \multirow{3}{*}{$\begin{array}{l}\text { Test criti- } \\
\text { cal values: }\end{array}$} & $1 \%$ level & -3.4385 & & \multirow{3}{*}{$\begin{array}{l}\text { Test criti- } \\
\text { cal values: }\end{array}$} & $1 \%$ level & -3.4385 & \\
\hline & $5 \%$ level & -2.8650 & & & $5 \%$ level & -2.8650 & \\
\hline & $10 \%$ level & -2.5687 & & & $10 \%$ level & -2.5687 & \\
\hline \multicolumn{4}{|c|}{ Null Hypothesis: D(LKSE100) has a unit root } & \multicolumn{4}{|c|}{ Null Hypothesis: D(LGP) has a unit root } \\
\hline & & $\mathrm{t}-$ Stat. & Prob.* & & & $\mathrm{t}-$ Stat. & Prob.* \\
\hline \multicolumn{2}{|c|}{$\begin{array}{l}\text { Augmented Dickey-Fuller } \\
\text { test statistic }\end{array}$} & -26.7251 & 0.0000 & \multicolumn{2}{|c|}{$\begin{array}{l}\text { Augmented Dickey-Full- } \\
\text { er test statistic }\end{array}$} & -28.3611 & 0.0000 \\
\hline \multirow{3}{*}{$\begin{array}{l}\text { Test critica } \\
\text { values: }\end{array}$} & $1 \%$ level & -3.4385 & & \multirow{3}{*}{$\begin{array}{l}\text { Test critical } \\
\text { values: }\end{array}$} & $1 \%$ level & -3.4385 & \\
\hline & $5 \%$ level & -2.8650 & & & $5 \%$ level & -2.8650 & \\
\hline & $10 \%$ level & -2.5687 & & & $10 \%$ level & -2.5687 & \\
\hline
\end{tabular}

Note: *MacKinnon (1996) one-sided p-values.

Source: Own research. 
Table 3C. Unit Root Tests for Stationarity

Phillips-Perron \& Augmented Dickey-Fuller Tests statistic

Second sub-sample period from Jul 1, 2008 to June 30, 2012

\begin{tabular}{|c|c|c|c|c|c|c|c|}
\hline \multicolumn{4}{|c|}{ Null Hypothesis: D(LKSE100) has a unit root } & \multicolumn{4}{|c|}{ Null Hypothesis: D(LGP) has a unit root } \\
\hline & & Adj. $\mathrm{t}-$ Stat & Prob.* & & & Adj. $\mathrm{t}-$ Stat & Prob.* \\
\hline \multicolumn{2}{|c|}{$\begin{array}{l}\text { Phillips-Perron test } \\
\text { statistic }\end{array}$} & -24.4082 & 0.0000 & \multicolumn{2}{|c|}{ Phillips-Perron test statistic } & -30.369 & 0.0000 \\
\hline \multirow{3}{*}{$\begin{array}{l}\text { Test critical } \\
\text { values: }\end{array}$} & $1 \%$ level & -3.4380 & & \multirow{3}{*}{$\begin{array}{l}\text { Test critical } \\
\text { values: }\end{array}$} & $1 \%$ level & -3.4380 & \\
\hline & $5 \%$ level & -2.8648 & & & $5 \%$ level & -2.8648 & \\
\hline & $10 \%$ level & -2.5686 & & & $10 \%$ level & -2.5686 & \\
\hline
\end{tabular}

\begin{tabular}{|c|c|c|c|c|c|c|c|}
\hline \multicolumn{4}{|c|}{ Null Hypothesis: D(LKSE100) has a unit root } & \multicolumn{4}{|c|}{ Null Hypothesis: D(LGP) has a unit root } \\
\hline & & $\mathrm{t}-$ Stat. & Prob.* & & & $\mathrm{t}-$ Stat. & Prob.* \\
\hline \multicolumn{2}{|c|}{$\begin{array}{l}\text { Augmented Dickey-Full- } \\
\text { er test statistic }\end{array}$} & -24.3744 & 0.0000 & \multicolumn{2}{|c|}{$\begin{array}{l}\text { Augmented Dickey-Fuller } \\
\text { test statistic }\end{array}$} & -30.3599 & 0.0000 \\
\hline \multirow{3}{*}{$\begin{array}{l}\text { Test critical } \\
\text { values: }\end{array}$} & $1 \%$ level & -3.4380 & & \multirow{3}{*}{$\begin{array}{l}\text { Test critical } \\
\text { values: }\end{array}$} & $1 \%$ level & -3.4380 & \\
\hline & $5 \%$ level & -2.8648 & & & $5 \%$ level & -2.8648 & \\
\hline & $10 \%$ level & -2.5687 & & & $10 \%$ level & -2.5687 & \\
\hline
\end{tabular}

Note: *MacKinnon (1996) one-sided p-values.

Source: Own research.

Table 3D. Unit Root Tests for Stationarity

Phillips-Perron \& Augmented Dickey-Fuller Tests statistic

Third sub-sample from Jul 1, 2012 to June 30, 2016

\begin{tabular}{|c|c|c|c|c|c|c|c|}
\hline \multicolumn{4}{|c|}{ Null Hypothesis: D(LKSE100) has a unit root } & \multicolumn{4}{|c|}{ Null Hypothesis: D(LGP) has a unit root } \\
\hline & & Adj. t-Stat & Prob.* & & & Adj. $\mathrm{t}-$ Stat & Prob.* \\
\hline \multicolumn{2}{|c|}{$\begin{array}{l}\text { Phillips-Perron test } \\
\text { statistic }\end{array}$} & -36.1028 & 0.0000 & \multicolumn{2}{|c|}{ Phillips-Perron test statistic } & -41.2684 & 0.0000 \\
\hline \multirow{3}{*}{$\begin{array}{l}\text { Test critical } \\
\text { values: }\end{array}$} & $1 \%$ level & -3.4380 & & \multirow{3}{*}{$\begin{array}{l}\text { Test critical } \\
\text { values: }\end{array}$} & $1 \%$ level & -3.4380 & \\
\hline & $5 \%$ level & -2.8648 & & & $5 \%$ level & -2.8648 & \\
\hline & $10 \%$ level & -2.5686 & & & $10 \%$ level & -2.5686 & \\
\hline \multicolumn{4}{|c|}{ Null Hypothesis: D(LKSE100) has a unit root } & \multicolumn{4}{|c|}{ Null Hypothesis: D(LGP) has a unit root } \\
\hline & & $\mathrm{t}-$ Stat. & Prob.* & & & $\mathrm{t}-$ Stat. & Prob.* \\
\hline \multicolumn{2}{|c|}{$\begin{array}{l}\text { Augmented Dickey- } \\
\text { Fuller test statistic }\end{array}$} & -36.2545 & 0.0000 & \multicolumn{2}{|c|}{$\begin{array}{l}\text { Augmented Dickey-Fuller } \\
\text { test statistic }\end{array}$} & -41.3689 & 0.0000 \\
\hline \multirow{3}{*}{$\begin{array}{l}\text { Test critical } \\
\text { values: }\end{array}$} & $1 \%$ level & -3.4380 & & \multirow{3}{*}{$\begin{array}{l}\text { Test critical } \\
\text { values: }\end{array}$} & $1 \%$ level & -3.4380 & \\
\hline & $5 \%$ level & -2.8648 & & & $5 \%$ level & -2.8648 & \\
\hline & $10 \%$ level & -2.5686 & & & $10 \%$ level & -2.5686 & \\
\hline
\end{tabular}

Note: *MacKinnon (1996) one-sided p-values.

Source: Own research. 
VAR Lag Order Estimation. As stock returns data series has become stationary at first difference, and the data series of gold returns is also integrated of order one, therefore, the Johansen cointegration test is suggested. In order to find out the appropriate lag length, we employed the lag length selection criteria that followed the Akaike (1973) information criterion (AIC). The AIC has proposed 2 lags for all data series in first, second, and third sub-sample periods, and the full sample period as well.

Johansen Cointegration Test Results. This test is applied to find out if cointegration exists and also to determine the figure of cointegration relation, whether it is long-term between equity returns and gold returns. The results in Table 4, for the full sample period, showed a long-term association between equity returns and gold returns. The outcomes of Table 4 further indicate that both variables are cointegrated because both approaches such as Trace test and Max-Eigen-value test have rejected the null hypothesis of no cointegration. Thus, it has further confirmed the existence of 2 significant cointegrating vectors that demonstrated 2 common stochastic trends in the model, and this is also an evidence of market cointegration. Hence, it indicates existence of stationarity and confirmed the long run relationship between equity returns of KSE100 and returns of gold.

Results of Granger Causality Technique. We have employed a pair-wise Granger causality technique that helps in highlighting the causal relationship between each factor. Since we have to select a lag in order to get proper results that is user-counted to check the sessions calculation. Table 5 shows that there is a

Table 4. Johansen Cointegration Test Result (Trace \& Max-Eigenvalue)

Unrestricted Cointegration Rank Test (Trace \& Max-Eigenvalues)

Full sample period from Jan 1, 2000 to June 30, 2016

\begin{tabular}{l|c|c|c|c}
\hline $\begin{array}{l}\text { Hypothesized no. } \\
\text { of CE(s) }\end{array}$ & Eigen-value & Trace-statistic & $\begin{array}{c}0.05 \\
\text { Critical values }\end{array}$ & Prob.** \\
\hline None* & 0.0068 & 55.86 & 28.50 & 0.0000 \\
\hline At most 1* & 0.0021 & 12.32 & 15.50 & 0.1892 \\
\hline At most 2 & 0.0007 & 3.75 & 4.95 & 0.1376 \\
\hline \multicolumn{4}{|c}{} \\
\hline $\begin{array}{l}\text { Hypothesized no. } \\
\text { of CE(s) }\end{array}$ & Eigen-value & $\begin{array}{c}\text { Max-Eigen- } \\
\text { statistic }\end{array}$ & $\begin{array}{c}0.05 \\
\text { Critical values }\end{array}$ & Prob.** \\
\hline None* & 0.0068 & 39.89 & 22.15 & 0.0000 \\
\hline At most 1* & 0.0021 & 10.66 & 13.96 & 0.2694 \\
\hline At most 2 & 0.0007 & 3.75 & 4.95 & 0.1376 \\
\hline
\end{tabular}

Notes: Both Trace \& Max-Eigenvalue Tests signify 2 cointegrating equ(s) at 0.05 levels. * indicates rejection of null hypothesis at 0.05 significance level, ** MacKinnon-Haug-Michelis (1999) p-values. Lags interval (in first difference): 1 to 4 .

Source: Own research. 
unidirectional causality from gold prices to KSE100 index in lag 1, but bi-directional causality existed between KSE 100 index and gold price in lag 2. It is also important to comprehend that even if there is a causality among the variables, it does not evidence the movement of one variable due to the movement of another variable. It is well known, to a certain degree that causality fundamentally is unavoidable for the movements in time series (Awe 2012).

Table 5. Pair-wise Granger Causality Tests

Full sample period from Jan 1, 2000 to June 30, 2016

\begin{tabular}{l|c|c|c|c}
\hline Lags: 1 & Obs. & F-Statistic & Prob. & Decision \\
\hline Null Hypothesis: & 4060 & 4.84254 & 0.0120 & Reject Ho \\
\hline $\begin{array}{l}\text { DLGP does not Granger Cause } \\
\text { DLKSE100 }\end{array}$ & & 2.17974 & 0.2517 & Does not reject Ho \\
\hline $\begin{array}{l}\text { DLKSE100 does not Granger } \\
\text { Cause DLGP }\end{array}$ & & F-Statistic & Prob. & Decision \\
\hline \begin{tabular}{l|l} 
Lags: 2 \\
Null Hypothesis:
\end{tabular} & Obs. & 5.13855 & 0.0311 & Reject Ho \\
\hline $\begin{array}{l}\text { DLGP does not Granger Cause } \\
\text { DLKSE100 }\end{array}$ & 4060 & 2.06664 & 0.0525 & Reject Ho \\
\hline $\begin{array}{l}\text { DLKSE100 does not Granger } \\
\text { Cause DLGP }\end{array}$ & & &
\end{tabular}

Source: Own research.

First sub-sample period: Jan 1, 2000 - June 30, 2008. Table 1 shows that in the first sub-sample period, the average stock returns were $0.11 \%$ daily or $33 \%$ annually, while the gold returns were $0.06 \%$ daily or $18 \%$ annually. It shows that the average stock returns are significantly much higher in the first sub-sample period than in comparison to the full sample period. Moreover, the stock returns are also much higher than the gold returns in the first sample period. Standard deviation shows the higher volatility in this sample period for both stock returns and gold returns too. Moreover, Kurtosis values again reject normality in both data series. Total observations of 2078 were considered after adjustments.

Correlation analysis. The outcomes of Table 2 exhibit negative correlation between equity returns and gold returns in the first sub-sample period that demonstrates an inverse association between KSE100 returns and returns of gold. Thus, this is the evidence that investors divert their investments from stock market to gold in the declining period or the other way round.

Johansen Cointegration Test Results. The results of Table 6 for the first sub-sample period, showed a long-term association between equity returns and gold returns. The outcomes of Table 6 further indicate that both variables are 
cointegrated because both approaches such as Trace test and Max-Eigen-value test have rejected the null hypothesis of no cointegration. Thus, it has further confirmed the existence of 1 significant cointegrating vector that demonstrated 1 common stochastic trend in the model, and this is also an evidence of market cointegration. Hence, it indicates an existence of stationarity and confirmed the long run relationship between equity returns of KSE100 and returns to gold in the first sub-sample period.

Table 6. Johansen Cointegration Test Result (Trace \& Max-Eigenvalue)

Unrestricted Cointegration Rank Test (Trace \& Max-Eigenvalues)

First sub-sample period from Jan 1, 2000 to June 30, 2008

\begin{tabular}{l|c|c|c|c}
\hline $\begin{array}{l}\text { Hypothesized } \\
\text { No. of CE(s) }\end{array}$ & Eigenvalue & $\begin{array}{c}\text { Trace } \\
\text { Statistic }\end{array}$ & $\begin{array}{c}0.05 \\
\text { Critical Value }\end{array}$ & Prob. $^{* *}$ \\
\hline None & 0.0065 & 57.0387 & 29.7971 & 0.0000 \\
\hline At most 1 & 0.0036 & 6.5059 & 15.4947 & 0.6357 \\
\hline At most 2 & 0.0004 & 0.6932 & 3.8415 & 0.4051 \\
\hline \multicolumn{5}{|l}{} \\
\hline $\begin{array}{l}\text { Hypothesized } \\
\text { No. of CE(s) }\end{array}$ & $\begin{array}{c}\text { Max-Eigen- } \\
\text { Statistic }\end{array}$ & $\begin{array}{c}0.05 \\
\text { Critical Value }\end{array}$ & Prob. ${ }^{* *}$ \\
\hline None & 0.0065 & 30.5328 & 21.1316 & 0.0000 \\
\hline At most 1 & 0.0036 & 5.8127 & 14.2646 & 0.6374 \\
\hline At most 2 & 0.0004 & 0.6932 & 3.8415 & 0.4051 \\
\hline
\end{tabular}

Notes: Both Trace \& Max-Eigenvalue Tests signify 1 cointegrating equ(s) at 0.05 levels. * indicates rejection of null hypothesis at 0.05 significance level, ** MacKinnon-Haug-Michelis (1999) p-values. Lags interval (in first difference): 1 to 4 .

Source: Own research.

Results of Granger Causality Technique. It is confirmed from Table 7 that there was no causality between KSE100 stock returns and gold returns in either direction in lag 1, but unidirectional causality existed between KSE100 index and gold price in lag 2 from gold prices to equity prices in the first sub-sample period.

Second sub-sample period: July1, 2008 - June 30, 2012. The global financial crises had started in 2008 and eventually converted into global economic recession from 2008 to 2012. Every financial market of the World had crashed in 2008, faced a deep financial crisis and had shown a declining trend in this period. Figure 1 also shows a structural break and continuous declining in KSE100 index during this time frame. Thus, considering the second sub-sample period, we address this problem when KSE100 index was declining, but intense and continuous investments were made in gold prices during that period. The results of our 
Table 7. Pairwise Granger Causality Tests

First sub-sample period from Jan 1, 2000 to June 30, 2008

\begin{tabular}{l|c|c|c|c}
\hline \multicolumn{5}{c}{ Lags: 1 } \\
\hline Null Hypothesis: & Obs. & F-Statistic & Prob. & Decision \\
\hline $\begin{array}{l}\text { DLGP does not Granger Cause } \\
\text { DLKSE100 }\end{array}$ & 993 & 2.14120 & 0.1192 & Does not reject Ho \\
\hline $\begin{array}{l}\text { DLKSE100 does not Granger Cause } \\
\text { DLGP }\end{array}$ & & 2.28965 & 0.2176 & Does not reject Ho \\
\hline
\end{tabular}

\begin{tabular}{l|c|c|c|c}
\hline \multicolumn{7}{|c}{ Lags: 2} & Decision \\
\hline Null Hypothesis: & Obs. & F-Statistic & Prob. & Reject Ho \\
\hline $\begin{array}{l}\text { DLGP does not Granger Cause } \\
\text { DLKSE100 }\end{array}$ & 993 & 4.49850 & 0.0405 & \\
\hline $\begin{array}{l}\text { DLKSE100 does not Granger Cause } \\
\text { DLGP }\end{array}$ & & 1.03525 & 0.3544 & Does not reject Ho \\
\hline
\end{tabular}

Source: Own research.

research also proved the deteriorating behavior of KSE100 index and its impact on gold prices as follows:

Descriptive analysis. Table 1 shows that the results of returns were entirely different as compared to the previously discussed first sub-period, stock returns show daily $0.01 \%$ returns or annually $3 \%$, whereas, daily gold returns were $0.08 \%$ or $24 \%$ annually. It shows that the average gold returns are much higher as compared to the previous sub-periods, and it is also noted that the gold returns are significantly higher than the stock returns in the second sample period. Thus, these results proved that gold was gaining the utmost attention of local and international investors and they diverted their investment from stock market to gold market in Pakistan. Standard deviation shows higher volatility in this sample period for both equity returns and returns of gold. The outcomes of the second sub-period confirmed the trend of Gold prices \& KSE100 when the second structural break has taken place and gold prices surpass the stock returns. Total observations of 993 were taken after adjustments for the second sub-period.

Correlation analysis. The outcomes of Table 2 again exhibit negative correlation between equity returns and gold returns in the second sub-sample period that demonstrates an inverse association between KSE100 returns and returns of gold. Thus, this is the evidence that investors divert their investments from stock market to gold in the declining period specifically for the second sub-sample period.

Johansen Cointegration Test Results. The results of Table 8, for the second sub-sample period, show no existence of the long-term association between equity returns and gold returns. Table 8 further indicates that both variables are not cointegrated because both approaches such as Trace test and Max-Eigen-value 
Table 8. Johansen Cointegration Test Result (Trace \& Max-Eigenvalue)

Unrestricted Cointegration Rank Test (Trace \& Max-Eigenvalues)

Second sub-sample period from Jul 1, 2008 to June 30, 2012

\begin{tabular}{l|c|c|c|c}
\hline $\begin{array}{l}\text { Hypothesized } \\
\text { No. of CE(s) }\end{array}$ & Eigenvalue & $\begin{array}{c}\text { Trace } \\
\text { Statistic }\end{array}$ & $\begin{array}{c}0.05 \\
\text { Critical value }\end{array}$ & Prob. $* *^{*}$ \\
\hline None & 0.0186 & 16.0187 & 29.7971 & 0.6482 \\
\hline At most 1 & 0.0026 & 6.5059 & 15.4947 & 0.6298 \\
\hline At most 2 & 0.0003 & 0.5832 & 3.8415 & 0.3951 \\
\hline \multicolumn{5}{|c}{} \\
\hline $\begin{array}{l}\text { Hypothesized } \\
\text { No. of CE(s) }\end{array}$ & $\begin{array}{c}\text { Max-Eigen } \\
\text { Statistic }\end{array}$ & $\begin{array}{c}0.05 \\
\text { Critical value }\end{array}$ & Prob. ${ }^{* *}$ \\
\hline None & 0.0186 & 11.7328 & 21.1316 & 0.6936 \\
\hline At most 1 & 0.0026 & 5.8127 & 14.2646 & 0.6274 \\
\hline At most 2 & 0.0003 & 0.5832 & 3.8415 & 0.3951 \\
\hline
\end{tabular}

Notes: Both Trace \& Max-Eigenvalue Tests signify 0 cointegrating equ(s) at 0.05 levels. * indicates rejection of null hypothesis at 0.05 significance level, ** MacKinnon-Haug-Michelis (1999) p-values. Lags interval (in first difference): 1 to 4 .

Source: Own research.

test have not rejected the null hypothesis of no cointegration. Thus, it is further confirmed that there is no existence of cointegrating vector in the model. Hence, it indicates that there is no long-run relationship between equity returns of KSE100 and returns of gold in the second sub-sample period.

Results of Granger Causality Technique. We have employed a pair-wise Granger causality technique that helps in highlighting the causal relationship between each factor. Since we have to select a lag in order to get proper results that is user-counted to check the sessions calculation. Table 9 shows that there is no

Table 9. Pairwise Granger Causality Tests

Second sub-sample period from Jul 1, 2008 to June 30, 2012

\begin{tabular}{l|c|c|c|c}
\hline \multicolumn{5}{|c}{ Lags: 1} \\
\hline Null Hypothesis: & Obs. & F-Statistic & Prob. & Decision \\
\hline $\begin{array}{l}\text { DLGP does not Granger Cause } \\
\text { DLKSE100 }\end{array}$ & 2078 & 0.94154 & 0.3390 & Does not reject Ho \\
\hline $\begin{array}{l}\text { DLKSE100 does not Granger } \\
\text { Cause DLGP }\end{array}$ & & 0.17974 & 0.6787 & Does not reject Ho \\
\hline
\end{tabular}

Lags: 2

\begin{tabular}{l|c|c|c|c}
\hline Null Hypothesis: & Obs. & F-Statistic & Prob. & Decision \\
\hline $\begin{array}{l}\text { DLGP does not Granger Cause } \\
\text { DLKSE100 }\end{array}$ & 2078 & 1.12845 & 0.3205 & Does not reject Ho \\
\hline $\begin{array}{l}\text { DLKSE100 does not Granger } \\
\text { Cause DLGP }\end{array}$ & & 0.12621 & 0.9355 & Does not reject Ho \\
\hline
\end{tabular}

Source: Own research. 
causality between KSE100 stock returns and gold returns in either direction in lag 1. Similarly, in lag 2 there is no evidence of any causality in either direction, thus, it implies that in the second sub-sample period no variables Granger cause another.

Third sub-sample period: July 1, 2012 - June 30, 2016. After the financial crises, investors moved into the precious metal market, and investors diverted their investments in gold. Figure 1 shows evidence that there was a continuous increase in international gold prices during the period from 2008 to 2011 and prices peaked in 2011. But at the end of 2011, there was a continuous decline in gold prices. So, this was the third structural break in our data due to regular decline in gold prices, but at the same time KSE100 index was recovering and gaining momentum. Therefore, the third sub-sample period is very important to establish the relationship between stock returns and gold returns when both variables get apart and swinging towards different poles. The results of our study for this period also demonstrated comprehensively for this phenomenon.

Descriptive analysis. Table 1 represents the descriptive analysis of equity returns of KSE100 and the daily returns of international gold prices. The results of Figure 1 and Table 1 clearly demonstrated that there is another structural break in data time series because the stock returns suddenly rise and reach the level of $0.12 \%$ daily or $36 \%$ annual returns, but at the same time there is a sharp decline in gold returns and it becomes negative i.e. $-0.02 \%$ daily or $-6 \%$ annual returns. These results are very much on similar line with the international financial markets as happened in Pakistan when investors again moved into KSE100 stock market because of declining returns to gold. Standard deviation again shows the higher volatility in the third sub-sample period for both stock returns and gold returns. Total observations of 990 were considered after adjustments.

Correlation analysis. The outcomes of Table 2 strikingly show the positive but insignificant correlation between equity returns and gold returns in the third subsample period that demonstrates a direct association between KSE100 returns and returns of gold. It is further concluded that the gold prices and the stock prices move together but yield a difference, which clearly indicates that the investors are in favor of stock returns rather than gold returns during the third sub-sample period.

Johansen Cointegration Test Results. The results of Table 10, for the third sub-sample period, show no existence of a long-term association between equity returns and gold returns. Table 10 further indicates that both variables are not cointegrated because both approaches such as Trace test and Max-Eigen-value test have not rejected the null hypothesis of no cointegration. Thus, it is further confirmed that there is no existence of cointegrating vector in the model. Hence, it is implied that there is no long-run relationship between equity returns of KSE100 and returns of gold in the third sub-sample period. Figure 1 also 
depicts that there is a structural break and both data time series are getting apart in this period and the outcomes of Johansen cointegration also substantiated the existence of no long-term association in the third sub-sample period.

Results of Granger Causality Technique. We have employed a pair-wise Granger causality technique that helps in highlighting the causal relationship between each factor. Since we have to select a lag in order to get proper results that is user-counted to check the sessions calculation. Table 11 shows that there is no

Table 10. Johansen Cointegration Test Result (Trace \& Max-Eigenvalue)

Unrestricted Cointegration Rank Test (Trace \& Max-Eigenvalues)

Third sub-sample period from Jul 1, 2012 to June 30, 2016

\begin{tabular}{l|c|c|c|c}
\hline $\begin{array}{l}\text { Hypothesized } \\
\text { No. of CE(s) }\end{array}$ & Eigen-value & $\begin{array}{c}\text { Trace- } \\
\text { Statistic }\end{array}$ & $\begin{array}{c}0.05 \\
\text { Critical value }\end{array}$ & Prob. $^{* *}$ \\
\hline None & 0.0898 & 15.6781 & 29.7971 & 0.7871 \\
\hline At most 1 & 0.0336 & 5.9843 & 14.2646 & 0.7210 \\
\hline At most 2 & 0.0005 & 1.8856 & 3.8415 & 0.1610 \\
\hline \multicolumn{5}{|c}{} \\
\hline Hypothesized & Max-Eigen- & $\begin{array}{c}0.05 \\
\text { Critical value }\end{array}$ & Prob. ${ }^{* *}$ \\
\hline None CE(s) & Eigen-value & Statistic & 21.1316 & 0.7698 \\
\hline At most 1 & 0.0885 & 12.4560 & 14.2646 & 0.7122 \\
\hline At most 2 & 0.0335 & 5.8890 & 3.8415 & 0.1638 \\
\hline
\end{tabular}

Notes: Both Trace \& Max-Eigenvalue Tests signify 0 cointegrating equ(s) at 0.05 levels. * indicates rejection of null hypothesis at 0.05 significance level, ** MacKinnon-Haug-Michelis (1999) p-values. Lags interval (in first difference): 1 to 4 .

Source: Own research.

Table 11.Pairwise Granger Causality Tests

Third sub-sample period from Jul 1, 2012 to June 30, 2016

\begin{tabular}{l|c|c|c|c}
\hline \multicolumn{5}{|c}{ Lags: 1} \\
\hline Null Hypothesis: & Obs. & F-Statistic & Prob. & Decision \\
\hline $\begin{array}{l}\text { DLGP does not Granger Cause } \\
\text { DLKSE100 }\end{array}$ & 990 & 3.75424 & 0.2295 & Does not reject Ho \\
\hline $\begin{array}{l}\text { DLKSE100 does not Granger } \\
\text { Cause DLGP }\end{array}$ & & 2.38952 & 0.1299 & Does not reject Ho \\
\hline
\end{tabular}

Lags: 2

\begin{tabular}{l|c|c|c|c}
\hline Null Hypothesis: & Obs. & F-Statistic & Prob. & Decision \\
\hline $\begin{array}{l}\text { DLGP does not Granger Cause } \\
\text { DLKSE100 }\end{array}$ & 990 & 2.37812 & 0.1421 & Does not reject Ho \\
\hline $\begin{array}{l}\text { DLKSE100 does not Granger } \\
\text { Cause DLGP }\end{array}$ & & 1.12828 & 0.3092 & Does not reject Ho \\
\hline
\end{tabular}

Source: Own research. 
Granger causality between KSE100 stock returns and gold returns in either direction in lag 1 . Similarly, in lag 2 there is no evidence of any causality in either direction, thus, it implies that in the third sub-sample period no variables Granger cause one another.

\section{DISCUSSION}

The findings of this research can be segregated into four panels of a dataset, the first panel contains the full sample period, however, the remaining three panels are classified into the first sub-sample period, the second sub-sample period, and the third sub-sample period. These three sub-sample periods are classified on the basis of three structural breaks, which we have identified from the overall data time series trends (Figure 1). Findings of the full time period and the first subsample period clearly demonstrated significant equity returns as compared to gold returns, and Johansen cointegration suggested a long-term association between equity returns of KSE100 and returns of gold in these periods. Thus, the outcomes of our study are in similar line with previous research studies, for instance, Pilinkus 2009; Baur - Lucey 2010; Sharma - Mahendru 2010; Wang et al. 2010; Mishra - Mohan 2012. The results of our study have shown a bidirectional causality between equity returns and returns of gold in lag 2 , a unidirectional causality in lag 1 for the full sample period and a unidirectional causality from gold returns to stock returns in the first period of sub-sample. Hence, these findings are in line with the past literature that also established a long-run association between equity prices and crude oil and gold prices with the same unidirectional causality.

Apart from the results of panel one of the full sample period, and the second panel of the first sub-sample period, we have also estimated the outcomes of the second and the third sub-sample periods as well. The outcomes of Johansen cointegration established that there is no evidence of any cointegrating vectors in panel three and panel four data series. Hence, it is finally concluded that the equity returns and gold returns do not have a long-run association in the third and the fourth sub-sample periods. The previous literature also supported this viewpoint; several past studies have concluded the same results between equity returns and gold returns. For example, Shahzadi - Chohan (2010), Kaliyamoorthy - Parithi (2012) discovered no long-run association between equity returns and returns of gold. Yahyazadehfar - Babaie (2012) concluded a negative relation amongst gold returns, nominal interest rate, and stock returns. In another study, Smith (2002) concluded a limited and negative short-term relation between stock returns and gold returns but no relation in the long-term in Europe and Japan. Similarly, Lawrence (2003) concluded that there is a near to the ground inter- 
relation between stock returns and gold, which makes gold a proficient portfolio diversifier.

We segregated our total sample in three sub-sample periods because of structural breaks, in which the behaviors of both variables are different due to different factors like global financial crises that were the most crucial phenomenon within our selected time horizon. Specifically, gold is not considered as a local instrument of investment, but it is regarded as an international de facto commodity. Therefore, the gold prices do not depend only on local dynamics but on the macroeconomic considerations, as well. The previous literature on this subject matter unveiled that the gold prices are traded in terms of US dollar, thus, they are also reliant on the political and economic conditions of the world. Moreover, the crude oil prices also influence the international gold prices (Koutsoyiannis 1983; Ghosh et al. 2002; Vural 2003; Tully - Lucey 2005; Topcu 2010; Toraman et al. 2011).

\section{CONCLUSION}

The results of our study confirmed the evidence regarding the long-run association between gold returns, and equity returns of KSE100 as demonstrated by Johansen cointegration analysis in the full sample period and the first sub-sample period. Descriptive analysis exhibited that returns in stock are much higher as compared to the gold prices in almost all the sample periods except the second sub-sample period when global financial crises have emerged and all the stock markets of the world had crashed and investors moved towards the gold markets. During that specific period, gold returns were significantly higher than the stock returns. The volatility or the risk was also much higher in all the sample periods for both variables. It also concludes an inverse association between stock returns and returns of gold as demonstrated by the correlation analysis. It can be interpreted that the investors are very much rational about the downfall of any market, thus they switch their investments from respective markets whenever they experience any downfall. The Granger causality identified a bidirectional causation between the variables in the full sample period in lag 2, and unidirectional causality has been observed from gold prices to stock prices in the full and the first sub-sample periods in lag 1 and lag 2, respectively. However, in the second and the third sub-sample periods there was no evidence of any causation in either direction for any variable.

Overall results showed a progressive sign and impact existed between KSE100 returns and gold returns. However, the econometric debate on the short-run or the long-run impact is still going on but at least these econometric financial models 
provide the basis to examine the influence of gold returns on the stocks and hence offering a valuable foil to researchers for further analysis. Then it will be established to make a conclusive and robust inference, and endorsement could be specified for the investors, researchers, and decision-making government institutions.

\section{REFERENCES}

Akaike, H. (1973): Information Theory and an Extension of the Maximum Likelihood Principle. In: Petrov, B. N. - Csáki, F.: 2nd International Symposium on Information Theory, Tsahkadsor, Armenia, USSR, September 2-8, 1971. Budapest: Akadémiai Kiadó, pp. 267-281.

Akash, R. S. I. - Hasan, A. - Javid, M. A. - Shah, S. Z. A. - Khan, M. I. (2011): Co-Integration and Causality Analysis of Dynamic Linkage between Economic Forces and Equity Market: An Empirical Study of Stock Returns and Macroeconomic Variables (Money Supply, Inflation, Interest Rate, Exchange Rate, Industrial Production and Reserves). African Journal of Business Management, 5(27): 10940-10964.

Aksoy, M. - Topcu, N. (2013): Altın ile Hisse Senedi ve Enflasyon Arasındaki İlişki (The Relationship between Gold, Stocks and Inflation). Atatürk Üniversitesi İktisadi ve İdari Bilimler Dergisi (Ataturk University Journal of Economics and Administrative Sciences), 27(1): 59-78.

Awe, O. O. (2012): On Pairwise Granger Causality Modelling and Econometric Analysis of Selected Economic Indicators. interstat statjournals.net/YEAR/2012/articles/1208002.pdf, 1-17.

Baig, M. M. - Shahbaz, M. - Imran, M. - Jabbar, M. - Ain, Q. U. (2013): Relationship between Gold \& Oil Price \& Stock Market Returns. Acta Universitatisdanubius, 9(5): 1-12.

Bali, S. - Cinel, M. O. (2011): Altın Fiyatlarının İMKB 100 Endeksi'ne Etkisi Ve Bu Etkinin Ölçümlenmesi (The Effect of Gold Prices on the ISE 100 Index and Measuring This Effect). Atatürk Üniversitesi İktisadive İdari Bilimler Dergisi (Atatürk University Journal of Economics and Administrative Sciences), 25(3-4): 45-63.

Baur, D. G. - Lucey, B. M. (2010): Is Gold a Hedge or a Safe Haven? An Analysis of Stocks, Bonds and Gold. Financial Review, 45(2): 217-229.

Baur, D. G. - McDermott, T. K. (2010): Is Gold a Safe Haven? International Evidence. Journal of Banking and Finance, 34(8): 1886-1898.

Bhunia, A. - Das, A. (2012): Association between Gold Prices and Stock Market Returns: Empirical Evidence from NSE. Journal of Exclusive Management Science, 1: 1-7.

Bhunia, A. - Mukhuti, S. (2013): Impact of Domestic Gold Price on Stock Price Indices - An Empirical Study of Indian Stock Exchanges. Universal Journal of Marketing and Business Research, 2(2): 35-43.

Blose, L. E. - Shieh, J. C. P. (1995): The Impact of Gold Price on the Value of Gold Mining Stock. Review of Financial Economics, 4(2): 125-139.

Bui, N. D. - Nguyen, L. T. B. - Nguyen, N. T. T. (2015): Herd Behaviour in Southeast Asian Stock Markets - An Empirical Investigation. Acta Oeconomica, (65)3: 413-429.

Büyüksalvarc1, A. (2010): The Effects of Macroeconomics Variables on Stock Returns: Evidence from Turkey. European Journal of Social Sciences, 14(3): 404-416.

Chan, H. - Faff, R. (1998): The Sensitivity of Australian Industry Equity Returns to a Gold Price Factor. Accounting and Finance, 38(2): 223-244.

Cheung, Y. W. - Lilian, K. N. (1998): International Evidence on the Stock Market and Aggregate Economic Activity. Journal of Empirical Finance, 5(3): 281-296. 
Daskalaki, C. - Skiadopoulos, G. (2011): Should Investors Include Commodities in Their Portfolio after All? New Evidence. Journal of Banking and Finance, 35(10): 2606-2626.

Dickey, D. A. - Fuller, W. A. (1979): Distribution of Estimators for Autoregressive Time Series with a Unit Root. Journal of the American Statistical Association, 74: 427-431.

Dickey, D. A. - Fuller, W. A. (1981): Likelihood Ratio Statistics for Autoregressive Time Series with a Unit Root. Econometrica, 49: 1057-1072.

Dickey, J. O. - Ghil, M. - Marcus, S. L. (1991): Extra Tropical Aspects of the 40-50 Day Oscillation in Length-of-Day and Atmospheric Angular Momentum. Journal of Geophysical Research, 96(22): 643-658.

Fama, E. F. (1981): Stock Returns, Real Activity, Inflation, and Money. The American Economic Review, 71(4): 545-565.

Filiz, Y. C. - Hümeyra, B. - Bener, G. (2013): Effect of Gold Price Volatility on Stock Returns: Example of Turkey. International Journal of Economics and Finance Studies, 5(1): 119-140.

Ghosh, D. - Levin, E. J. - Macmillan, P. - Wright, R. E. (2002): Gold as an Inflation Hedge? Discussion Paper. Department of Economics, University of St. Andrews.

Gong, F. - Mariano, R. S. (1997): Stock Market Returns and Economic Fundamentals in an Emerging Market: The Case of Korea. Financial Engineering and the Japanese Markets, 4(2): 147169.

Granger, C. W. J. (1969): Investigating Causal Relations by Econometric Models and Cross-Spectral Methods. Econometrica, 37(3): 424-438.

Gwilym, O. - Clare, A. - Seaton, J. - Thomas, S. (2011): Gold Stocks, the Gold Price and Market Timing. Journal of Derivatives and Hedge Funds, 17(3):266.

Hall, S. G. - Henry, S. G. B. (1989): Macro-Economic Modelling. Contributions to Economic Analysis, 172. North-Holland, Amsterdam: reprint.

Johansen, S. (1991): Estimation and Hypothesis Testing of Cointegration Vectors in Gaussian Vector Autoregressive Models. Econometrica, 59(6): 1551-1580.

Johansen, S. (1995): Likelihood-Based Inference in Cointegrated Vector Autoregressive Models. New York: Oxford University Press.

Johansen, S. - Juselius, K. (1990): Maximum Likelihood Estimation and Inference on Cointegration - With Applications to the Demand for Money. Oxford Bulletin of Economics and Statistics, 52(2): 169-210.

Kaliyamoorthy, D. S. - Parithi, M. S. (2012): Relationship of Gold Market and Stock Market: An Analysis. International Journal of Business and Management Tomorrow, 2(6): 1-6.

Koutsoyiannis, A. (1983): A Short-Run Pricing Model for a Speculative Asset, Tested with Data from the Gold Bullion Market. Applied Economics, 15: 563-581.

Lawrence, C. (2003): Why is Gold Different from Other Assets? An Empirical Investigation. London: World Gold Council.

MacKinnon, J. G. (1996): Numerical Distribution Functions for Unit Root and Cointegration Tests. Journal of Applied Econometrics, 11(6): 601-618.

MacKinnon, J. G. - Haug, A. A. - Michelis, L. (1999): Numerical Distribution Functions of Likelihood Ratio Tests for Cointegration. Journal of Applied Econometrics, 14(5): 563-577.

Mahdavi, S. - Zhou, S. (1997): Gold and Commodity Prices as Leading Indicators of Inflation: Tests of Long-Run Relationship and Predictive Performance. Journal of Economics and Business, 49(5): 475-489.

Mishra, P. K. - Das, J. R. - Mishra, S. K. (2010): Gold Price Volatility and Stock Market Returns in India. American Journal of Scientific Research, 9: 47-55.

Mishra, R. N. - Mohan, G. J. (2012): Gold Prices and Financial Stability in India. RBI Working Paper Series, Department of Economic and Policy Research, 2: 1-16.

Moore, G. H. (1990): Gold Prices and a Leadind Index of Inflation. Challenge, 33(4): 52-56. 
Mulyadi, M. S. - Anwar, Y. (2012): Gold Versus Stock Investment: An Econometric Analysis. International Journal of Development and Sustainability Online, 1(1): 1-7.

Nguyen, C. - Komorníková, M. - Komorník, J. - Bhatti, I. (2012): New Evidence on Asymmetric Movement between Gold Prices and Stock Markets with Mixed-Copula Analysis. Paper presented in World Finance and Banking Symposium, held at Shanghai, China, December 17-18, 2012.

Omağ, A. (2012): An Observation of the Relationship between Gold Prices and Selected Financial Variables in Turkey. Journal of Accounting and Finance, 55: 195-204.

Pakistan Stock Exchange (2016): Daily Stock Prices of KSE100 index. http://www.psx.com.pk/

Phillips, P. C. B. - Perron, P. (1988): Testing for a Unit Root in Time Series Regression. Biometrika, 75(2): 335-346.

Pilinkus, D. (2009): Stock Markets and Macroeconomic Variables: Evidences from Lithuania. Journal of Economics and Management, 14: 884-893.

Pritchard, A. E. (2010): Gold Reclaims Its Currency Status as the Global System Unravels. The Telegraph, 20 June.

Samadi, S. - Bayani, O. - Ghalandari, M. (2012): The Relationship between Macroeconomic Variables and Stock Returns in the Tehran Stock Exchange. International Journal of Academic Research in Business and Social Sciences, 2(6): 559-573.

Shahzadi, H. - Chohan, M. N. (2010): Impact of Gold Price on Stock Exchange: A Case Study of Pakistan. Presentation at the 3rd SAICON International Conference on Management, Business Ethics and Economics (ICMBEE), Institute of Information Technology, pp. 1-12, Lahore, Pakistan.

Sharma, G. D. - Mahendru, M. (2010). Impact of Macro-Economic Variables on Stock Prices in India. Global Journal of Management and Business Research, 10(7): 19-26.

Smith, G. (2001): The Price of Gold and Stock Price Indices for the United States. Adrienne Roberts FT Personal Finance. http://www.spdrgoldshares.com/media/GLD/file/Gold\%26USStockI ndicesDEC200120fina.pdf

Smith, G. (2002): London Gold Prices and Stock Price Indices in Europe and Japan. http://www. spdrgoldshares.com/media/GLD/file/GOLD\&EUJPStockIndicesFeb2002.pdf

Sumner, S. - Johnson, R. - Soenen, L. (2010): Spillover Effects between Gold, Stocks, and Bonds. Journal of Centrum Cathedra, 3(2): 106-120.

Trading Economics (2016): Daily International Gold Prices. www.tradingeconomics.com

Topçu, A. (2010): Altın Fiyatlarını Etkileyen Faktörler (Factors Affecting Gold Prices). SPK Araştırma Raporu (SPK Research Report), Ankara.

Toraman, C. - Başarir, Ç. - Bayramoğlu, M. (2011): Determination of Factors Affecting the Price of Gold: A Study of MGARCH Model. Business and Economics Research Journal, 2(4): 37-50.

Tully, E. - Lucey, B. M. (2005): An APGARCH Investigation of the Main Influences on the Gold Price. School of Business Studies and Institute for International Integration, University of Dublin Trinity College, Working Paper, August.

Vural, M. G. (2003): Altın Piyasasıve Altın Fiyatlarını Etkileyen Faktörler (Factors Affecting the Gold Market and Gold Prices). TCMB Uzmanlık Yeterlilik Tezi (CBRT Specialization Proficiency Thesis), Ankara.

Wang, M. - Wang, C. P. - Huang, T. (2010): Relationships among Oil Price, Gold Price, Exchange Rate and International Stock Markets. International Research Journal of Finance and Economics, 47: 80-89.

Yahyazadehfar, M. - Babaie, A. (2012): Macroeconomic Variables and Stock Price: New Evidence from Iran. Middle East Journal of Scientific Research, 11(4): 408-415. 